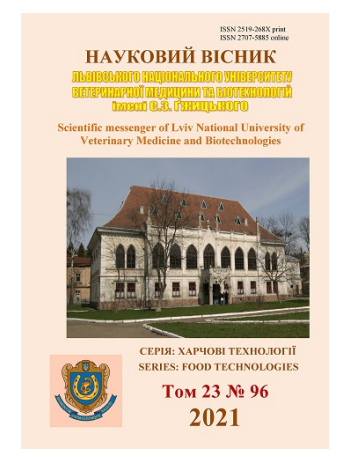

\author{
Науковий вісник Дьвівського національного університету \\ ветеринарної медицини та біотехнологій імені С.3. Гжицького. \\ Серія: Харчові технології \\ Scientific Messenger of Lviv National University \\ of Veterinary Medicine and Biotechnologies. \\ Series: Food Technologies

UDC 665.22..636.4.084.41/.42

\title{
Fatty acid composition of swine fat when using different feedstuffs in diets
}

\author{
N. Chyzhanska, A. Polishchuk \\ Poltava State Agrarian University, Poltava, Ukraine
}

Article info

Received 09.04.2021

Received in revised form 10.05 .2021

Accepted 11.05.2021

Poltava State Agrarian University, Skovorody Str., 1/3, Poltava, 36003, Ukraine.

Tel. : +38-099-621-07-87

E-mail:

nataliia.chyzhanska@pdaa.edu.ua
Chyzhanska, N., \& Polishchuk, A. (2021). Fatty acid composition of swine fat when using different feedstuffs in diets. Scientific Messenger of Lviv National University of Veterinary Medicine and Biotechnologies. Series: Food Technologies, 23(96), 19-22. doi: 10.32718/nvlvet-f9604

Human health is largely determined by the influence of environmental factors, including the quality of foodstuff. Nutrition is one of the most important factors, so the application of modern knowledge about the energy value and fatty acid composition of basic foods, as well as the organization of a rational diet of people on this basis can significantly improve it. This article analyses data on the fatty acid composition of fat when using different feedstuffs in swine diets. The use of additives in animal diets in order to increase their productivity affects the quality of products, in particular the fatty acid composition of swine fat, which influences the physical and chemical properties and technological properties of food products. The role of saturated and polyunsaturated fatty acids in human and animal bodies, which play an extremely important role in metabolism, is described. The data on their content in fat and swine products as the main source of these substances in the human diet are summarised. The importance of a balanced intake of polyunsaturated fatty acids in the human diet is discussed, which contributes to the prevention of various diseases, and a review of the results of studies on the effect of various feedstuffs on the fatty acid composition of swine products is given, since the content of individual fatty acids that are not synthesised in the animal body is affected by feed quality and the presence of fatty acids in lipids of feed, which determine the quality of human foods.

Key words: swine fat, fatty acids, diet, foodstuffs, product quality.

\section{Жирнокислотний склад сала свиней при використанні різних кормових засобів в раціонах}

\author{
Н. В. Чижанська, А. А. Поліщук
}

Полтавський державний аграрний університет, м. Полтава, Украӥна

\begin{abstract}
Здоров'я людини переважно визначається впливом факторів навколишнього середовища, у тому числі якістю харчових продуктів. Харчування є одним з найважливіших факторів, тому застосування сучасних знань про енергетичну иінність та жирно кислотний склад основних продуктів харчування, а також організацію на цій основі раціонального харчування людей дозволяє значно його підвищити. В даній статті наведено результати аналізу даних щодо жирнокислотного складу сала за умов використання різних кормових засобів у раціонах свиней. Застосування добавок, які використовують в раціонах тварин, $з$ метою підвищення їх продуктивності, впливає на якість продукиії, зокрема на жирнокислотний склад жиру свиней, від якого залежать фізико-хімічні та технологічні властивості продуктів харчування. Описується роль насичених та поліненасичених жирних кислот в організмі людини та тварин, які відіграють надзвичайно важливу роль в обміні речовин. Узагальнюються дані про їх вміст в салі та продукції свинарства як в основному джерелі иих речовин у харчуванні людини. Розглядається значення збалансованого спожсиваня поліненасичених жирних кислот в раціоні людей, що сприяє профілактииі різних захворювань, а також наводиться огляд результатів досліджень по впливу різних кормових засобів на жирно кислотний склад продукції свинарства, так як на вміст окремих жирних кислот, які не синтезуються в організмі тварин, впливає якість кормів та наявність жирних кислот у ліпідах кормах, що визначають якісні показники продуктів харчування для людей.
\end{abstract}

Ключові слова: жир свиней, жирні кислоти, продукти харчування, якість продукиї. 


\section{Вступ}

Жири тваринного та рослинного походження є необхідними компонентами раціону харчування людини, так як і білки та вуглеводи. Вони відіграють важливу роль в регуляції обміну речовин, депонують енергію, виконуючи захисну функцію організму, є розчинниками і переносниками вітамінів, гормонів, простагландинів, а також обов'язковою складовою частиною нервової тканини та структурними компонентами клітинної мембрани. Їх поживна цінність визначається жирнокислотним складом та розподіленням жирних кислот в молекулі триацилгліцеридів (Patel \& Brocks, 2009; Zaytseva, 2010; Trrzicka et al., 2011; Gladyshev, 2012; Liu et al., 2014; Pavlisova et al., 2016; Ye et al., 2019).

\section{Результати та їх обговорення}

Жири необхідно споживати щодня, проте їх доля в раціоні харчування невелика, денною нормою дорослої людини можна вважати 9-12 г сала, максимальна тижнева порція - 100 г, тоді від сала буде тільки користь, шкода буде відсутня. Воно є джерелом цінних і незамінних жирних кислот (Berhe et al., 2016). Micтить лецитин, який забезпечує еластичність судин, а також позитивно впливає на судини і клітинні мембрани, зміцнюючи їх (Yanty et al., 2011). Вільні жирні кислоти за допомогою хімічних реакцій можна перетворити на широкий асортимент біохімічних продуктів, які використовуються в харчових продуктах, ліках, хімічних та інших галузях промисловості (Huang et al., 2020).

Жирова тканина тварин майже на 90 \% складається $з$ насичених (пальмітинова та стеаринова) й мононенасичених (олеїнова) жирних кислот. На поліненасичені жирні кислоти припадає 10 \% від загальної кількості жирних кислот. Незважаючи на невелику їх кількість у тригліцеридах, вони відіграють надзвичайно важливу роль в організмі - стимулюють синтез білків та ліпідів, підвищують стійкість організму до інфекційних захворювань, підтримують активність ферментів, регулюють процеси окиснення й виконують інші, не менш важливі функції в організмі (Wood et al., 2008; Gladyshev, 2012).

Жирнокислотний склад і харчова цінність жиру характеризується вмістом біологічно активних речовин - жиророзчинних вітамінів, стеринів та фосфоліпідів. Корисні властивості сала в тому, що в ньому знаходяться вітаміни, мікроелементи (селен), жирні кислоти (насичені і ненасичені) (Birta et al., 2016). Найціннішою серед кислот, що містяться в салі, $є$ арахідонова кислота - поліненасичена жирна кислота, що має цілий спектр корисних дій, вона покращує роботу головного мозку, серцевого м'язу, впливає на роботу нирок і покращує склад крові, виводячи з неї зайві бляшки холестеринів. На вміст окремих жирних кислот, які не синтезуються в організмі тварин впливає якість кормів та наявність жирних кислот у ліпідах кормів, що впливає на якісні показники туші (Holinei \& Kvasha 2011). Харчова і біологічна цінність свинини залежить від жирнокислотного складу ліпідів у тканинах свиней (Berhe et al., 2016).

Лінолева та ліноленова кислоти беруть участь в утворенні клітинних мембран, оболонок нервових волокон і служать попередниками поліненасичених жирних омега-3 і омега-6 кислот. Для повного циклу метаболізму ненасичених жирних кислот важливим $€$ наявність в кормі насичених жирних кислот - пальмітинової і стеаринової. Вони слугують попередниками мононенасичених кислот - пальмітолеїнової і олеїнової, які використовуються для утворення тригліцеридів. Таким чином, поряд 3 високою енергетичною цінністю, жирні кислоти надають багатосторонню метаболічну та регуляторну дію (Patel \& Brocks, 2009). А також співвідношення жирних кислот є одним 3 найважливіших факторів харчової якості м'яса (Wood et al., 2008; Waszkiewicz-Robak et al., 2015; Glorieux et al., 2018) та бекону (Larsen et al., 2009). Регулюючи вміст жиру у кормах змінюється якість даних продуктів харчування.

Лецитин, що міститься в салі позитивно впливає на судини і клітинні мембрани, зміцнює їх, робить еластичнішими. За твердженнями дієтологів, речовини, що знаходяться в салі, запускають механізми розщеплення жирів. Крім цього, сало в обмеженій кількості вважається засобом профілактики раку i допомагає виводити токсини з організму (Simmons et al., 2015).

В меншій мірі, ніж качиний жир, але сало зменшує ліпотоксичність печінки, викликану пальмітиновою насиченою жирною кислотою (Kang et al., 2019), тобто зменшує пошкодження клітин, а також сприяє меншому підвищенню ліпемії після їжі, порівняно 3 пальмовою олією (Teng et al., 2011).

Сало є не лише національним продуктом харчування українців, його також активно використовують в їжу європейці. В результаті проведеного аналізу раціонів хачування польських та іспанських студентів фізкультурного факультету спостерігались суттєві відмінності у частоті споживання продуктів залежно від статі. Юнаки віддавали перевагу високонергетичним продуктам, в тому числі і салу (Gacek et al., 2020).

Фізико-хімічні властивості ліпідів та їх жирнокислотний склад змінюються під впливом умов годівлі свиней. Сало містить різну кількість ненасичених жирних кислот, залежно від системи вирощування та годівлі (Serra et al., 2014; Berhe et al., 2016). Висока концентрація насичених і мононенасичених жирних кислот у тригліцеридах тісно пов'язана з активним їх синтезом і нагромадженням в організмі навіть за утримання свиней на раціонах із низьким умістом жиру (Birta et al., 2016).

В Україні активно інвестуються вкладення в розвиток галузі свинарства, отримуючи повноцінні продукти харчування. 3 метою оптимізації раціонів по основних поживних та біологічно активних речовинах в раціонах свиней, як для вирощування так і для відгодівлі, використовують білково-вітамінно-мінеральні добавки, ферментні препарати та відходи переробки олійного виробництва. Використання кормових добавок $з$ вмістом жирних кислот та відходів переробки соняшнику в раціонах молодняку та свиней на відго- 
дівлі впливають на жирно кислотний склад шпику свиней.

За даними авторів (Bondarenko \& Hutsol, 2016). Білково-вітамінно-мінеральна добавка "Мінактивіт" 3 включенням комплексного препарату “Біло-актив", у складі якого міститься суміш алюмосилікатів, кальцію, евкаліпту та жирних кислот (капронова, каприлова, капринова та лауринова) та борошно свинячої крові, яке $є$ ідеальним джерелом протеїну на зміну загальної кількості ненасичених і насичених жирних кислот у хребтовому шпику препарат не впливає. Окремо препарат впливав на кількість насичених жирних кислот у хребтовому шпику свиней, за рахунок його використання підвищується вміст пальмітинової, міристинової, стеаринової та маргаринової кислот. По вмісту каприлової, капронової, лауринової, капринової, та арахінової жирних кислот дослідники змін не виявили.

Оскільки тільки насичені жирні кислоти синтезуються в організмі свиней, то, надходження в організм тварини ненасичених жирних кислот повинно забезпечуватися за рахунок їх вмісту в кормах, які використовуються для балансування раціонів. Ненасичені жирні кислоти (ліноленова, лінолева) кислоти регулюють холестериновий обмін, а також необхідні для здорового розвитку, росту та розмноження тварин. Вони мають позитивний вплив на обмін холестерину та вітамінів С, Р, групи В в організмі тварин. Підвищувати кількість лінолевої та ліноленової жирних кислот в раціонах свиней можливо за рахунок різних джерел жиру (Larsen et al., 2009; Sukhovukha, 2013; Waszkiewicz-Robak et al., 2015). Рівень лінолевої кислоти, який рекомендовано для молодняку свиней повинен становити 1,5 \% перетравної енергії, а для дорослого поголів'я свиней, яких вирощують для отримання високоякісного бекону, у заключний період відгодівлі - 0,7 \% (Sukhovukha, 2013). Як дефіцит, так і надлишок лінолевої кислоти негативно впливає на стан здоров'я тварин. Включення до раціону відгодівельних свиней лінолевої кислоти змінює жирнокислотний склад не лише жиру, але і позитивно впливає на якість бекону. Зменшується рівень окислення ліпідів свинячого жиру (Larsen et al., 2009).

За даними (Waszkiewicz-Robak et al., 2015) модифікація джерела жиру в кормах свиней не впливає на вміст білку та мінеральних речовин, тоді як суттєво впливає на вміст жиру та вологи в м'ясі свиней. Різне джерело жиру в кормах свиней не впливає на суму насичених та ненасичених жирних кислот у жирі, але суттєво впливає на вміст певних жирних кислот, що належать до моно ненасичених.

За рахунок додавання рослинної олії до складу раціону молодняку та дорослого поголів'я свиней в організм тварин надходить більше необхідних для нормального перебігу обміну речовин ненасичених жирних кислот (Sukhovukha, 2013). Додавання відстою соняшникової олії до раціону молодняку свиней має позитивний вплив на вміст незамінних жирних кислот в підшкірному салі. На 20,8 \% збільшилася кількість лінолевої кислоти, що вплинуло на підвищення іiі похідних, а саме ліноленової та ейкозадієнової, в ре- зультаті чого є можливість отримати сало збагачене незамінними жирними кислотами (Sukhovukha, 2013).

Дані, отримані в результаті досліджень по визначенню вмісту жирних кислот свідчать, що збагачення раціонів свиней ферментним препаратом МЕК-БТУ-6 “Данамікс" не має суттєвого впливу на зміну суми насичених і ненасичених жирних кислот в хребтовому шпику. Але мали місце зрушення по вмісту окремих жирних кислот. За рахунок даної добавки підвищується вміст насичених жирних кислот, а саме пальмітинової, стеаринової, маргаринової та арахінової кислот. А також збільшується кількість мононенасичених олеїнової, гондоїнової та маргаринолеїнової жирних кислот, що свідчить про те, що використання препарату в раціонах свиней сприяє підвищення вмісту поліненасичених жирних кислот в хребтовому шпику свиней (Hlavatchuk, 2014).

\section{Висновки}

Виконаний аналіз літературних джерел свідчить, що збагачення раціонів свиней різними кормовими засобами змінює жирнокислотний склад не лише жиру, але впливає і на якість бекону. Різне джерело жиру в кормах свиней не впливає на суму насичених та ненасичених жирних кислот у жирі, але суттєво впливає на вміст певних жирних кислот.

3 метою швидкого нарощування обсягів продукції галузі свинарства в раціонах тварин активно використовують біологічно активні добавки та відходи переробки олійного виробництва. Розробкою добавок для тварин займаються багато фірм, як України, так i Свропи та пропонують широкий асортимент добавок до раціонів різних видів та вікових груп тварин, що впливають на якість продуктів харчування, зокрема на якість сала. А корисні властивості сала відчутні у тому випадку, якщо вживати натуральний, екологічно чистий продукт.

\section{References}

Berhe, D. T., Eskildsen, C. E., Lametsch, R., Hviid, M. S., van den Berg, F., \& Engelsen, S. B. (2016). Prediction of total fatty acid parameters and individual fatty acids in pork backfat using Raman spectroscopy and chemometrics: Understanding the cage of covariance between highly correlated fat parameters. Meat Science, 111, 18-26. doi: 10.1016/j.meatsci.2015.08.009.

Birta, G., Byrgy, Yu., Nazarenko, V. \& Goryachova, O. (2016). Physical and chemical indices of subcutaneous lard pigs of different direction performance. Bìol. Tvarin, 18(4), 9-13. doi: 10.15407/animbiol18.04.009 (in Ukranian).

Bondarenko, V. V., \& Hutsol, A. V. (2016). Pokaznyky yakosti svynyny pry zghodovuvanni BVMD "Minaktyvit". Ahrarna nauka ta kharchovi tekhnolohii: zb. nauk. prats VNAU, 2(92), 15-21 (in Ukrainian).

Gacek, M., Kosiba, G., \& Wojtowicz, A. (2020). Frequency of consuming selected product groups among Polish and Spanish physic al education students. Rocz Panstw Zakl Hig, 71(3), 261-270. doi: 10.32394/rpzh.2020.0121. 
Gladyshev, M. Y. (2012). Nezamenimyye polynenasyshchennyye zhyrnyye kisloty i ih istochniki dlya cheloveka. Journal of Siberian Federal University. Biology, 4, 352-386 (in Russian).

Hlavatchuk, V. A. (2014). Zhyrnokyslotnyi sklad sala svynei pry zghodovuvanni fermentnoho preparatu MEK-BTU-6. Naukovyi visnyk LNUVMBT imeni S. Z. Hzhytskoho, 16(2(59), 36-41 (in Ukrainian).

Glorieux, S., Steen, L., De Brabanter, J., Foubert, I., \& Fraeye, I. (2018). Effect of Meat Type, Animal Fatty Acid Composition, and Isothermal Temperature on the Viscoelastic Properties of Meat Batters. Journal of Food Science, 83(6), 1596-1604. doi: 10.1111/17503841.14182.

Holinei, H. M., \& Kvasha, V. I. (2011). Vplyv vykorystannia $\mathrm{u}$ ratsionakh kabanchykiv roslynnykh vysokobilkovykh i zhyromistkykh kormiv u skladi rehionalnykh zernosumishei z BVMD-1 na yikh zabiini yakosti. Zbirnyk nauk. prats PDATU, 19, 37 39 (in Ukrainian).

Huang, J., Zhao, Q., Bu, W., Zhang, C., Yang, Z., Zhang, X., \& Zhang, K. (2020). Ultrasound-assisted hydrolysis of lard for free fatty acids catalyzed by combined two lipases in aqueous medium. Bioengineered, 11(1), 241250. doi: 10.1080/21655979.2020.1729678.

Kang, E. S., Hur, J., Jo, Y., Kim, H. J., Han, S. G., \& Seo, H. G. (2019). Comparative effects of nanoemulsions loaded with duck oil and lard oil on palmitate-induced lipotoxicity. Journal of Food Biochemistry, 44(2), e13117. doi: 10.1111/jfbc. 13117.

Larsen, S. T.,Wiegand, B.R., Parrish, Jr.F.C., Swan, J.E., \& Sparks, J. C. (2009). Dietary conjugated linoleic acid changes belly and bacon quality from pigs fed varied lipid sources. American Society of Animal Science. All rights reserved, 87(1), 285-295. doi: 10.2527/jas.2008.1213.

Liu, P., Kerr, B. J., Chen, C., Weber, T. E., Johnston, L. J., \& Shurson, G. C. (2014). Influence of thermally oxidized vegetable oils and animal fats on energy and nutrient digestibility in young pigs. Journal of Animal Science, 92(7), 2980-2986. doi: 10.2527/jas.2012-5711.

Migliaccio, V., Sica, R., Di Gregorio, I., Putti, R., \& Lionetti, L. (2019). High-Fish Oil and High-Lard Diets Differently Affect Testicular Antioxidant Defense and Mitochondrial Fusion/Fission Balance in Male Wistar Rats: Potential Protective Effect of $\omega 3$ Polyunsaturated Fatty Acids Targeting Mitochondria Dynamics. International Journal of Molecular Sciences, 20(12), 3110. doi: 10.3390/ijms20123110.

Patel, J. P., \& Brocks, D. R. (2009). The effect of oral lipids and circulating lipoproteins on the metabolism of drugs. Expert Opinion on Drug Metabolism \& Toxicology, 5(11), 1385-1398. doi: 10.1517/17425250903176439.
Pavlisova, J., Bardova, K., Stankova, B., Tvrzicka, E., Kopecky, J., \& Rossmeisl, M. (2016). Corn oil versus lard: Metabolic effects of omega-3 fatty acids in mice fed obesogenic diets with different fatty acid composition. Biochimie, 124, 150 162. doi: 10.1016/j.biochi.2015.07.001.

Serra, A., Buccioni, A., Rodriguez-Estrada, M. T., Conte, G., Cappucci, A., \& Mele, M. (2014). Fatty acid composition, oxidation status and volatile organic compounds in "Colonnata" lard from Large White or Cinta Senese pigs as affected by curing time. Meat Science, 97(4), 504-512. doi: 10.1016/j.meatsci.2014.03.002.

Simmons, G., Pruitt, W., \& Pruitt, K. (2015). Diverse Roles of SIRT1 in Cancer Biology and Lipid Metabolism. International Journal of Molecular Sciences, 16(1), 950-965. doi: 10.3390/ijms16010950.

Sukhovukha, S. M. (2013). Vplyv vidstoiu soniashnykovoi olii na zhyrnokyslotnyi sklad sala svynei. Naukovyi visnyk LNUVMBT imeni S. Z. Hzhytskoho, 1(55),191-194 (in Ukrainian).

Teng, K.-T., Nagapan, G., Cheng, H. M., \& Nesaretnam, K. (2011). Palm Olein and Olive Oil Cause a Higher Increase in Postprandial Lipemia Compared with Lard but Had No Effect on Plasma Glucose, Insulin and Adipocytokines. Lipids, 46(4), 381-388. doi: 10.1007/s11745-010-3516-y.

Tvrzicka, E, Kremmyda L.S., Stankova, B, \& Zak, A. (2011) Fatty acids as biocompounds: their role in human metabolism, health and disease--a review. Part 1: classification, dietary sources and biological functions. Biomedical Papers, 155(2), 117-130. doi: 10.5507/bp.2011.038.

Waszkiewicz-Robak, B., Szterk, A, Rogalski, M, Rambuszek, M, Kruk, M, \& Rokowska, E. (2015). Nutritional value of raw pork depending on the fat type contents in pigs feed. Acta Sci Pol Technol Aliment. 14(2). 153-163. doi: 10.17306/J.AFS.2015.2.17.

Wood, J. D., Enser, M., Fisher, A. V., Nute, G. R., Sheard, P. R., Richardson, \& R. I., Whittington, F. M. (2008). Fat deposition, fatty acid composition and meat quality: A review. Meat Science, 78(4), 343358. doi:10.1016/j.meatsci.2007.07.019.

Yanty, N. A. M., Marikkar, J. M. N., Man, Y. B. C., \& Long, K. (2011). Composition and Thermal Analysis of Lard Stearin and Lard Olein. Journal of Oleo Science, 60(7), 333-338. doi: 10.5650/jos.60.333.

Ye, Z., Li, R., Cao, C., Xu, Y.-J., Cao, P., Li, Q., \& Liu, Y. (2019). Fatty acid profiles of typical dietary lipids after gastrointestinal digestion and absorbtion: A combination study between in-vitro and in-vivo. Food Chemistry, 280, 34 -44. doi: 10.1016/j.foodchem.2018.12.032.

Zaytseva, L. V. (2010) Rol razlichnykh zhirnykh kislot v pitanii cheloveka i pri proizvodstve pishchevykh produktov. Pishchevaya promyshlennost, 10, 60-63 (in Russian). 